\title{
電気二重層コンデンサーの高性能化
}

\author{
石川正 司*，松田 好 晴*
}

\section{Development of Electric Double-Layer Capacitors}

\author{
Masashi ISHIKAWA* and Yoshiharu MATSUDA*
}

Key Words : Electric Double-Layer Capacitors, Cold Plasma, Carbon Electrode, Solid Electrolyte

非水電解質を含有する電気二重層コンデンサーの高性能化を目的とした, コンデンサー用炭素電極材 料の表面処理技術である低温プラズマ処理法と, 電解質の改良について, 我々のアプローチを中心に紹 介する。

\section{1.はじめに}

コンデンサーでありながらいわゆる二次電池（ニッカ ド電池, リチウム二次電池など）にせまる大容量を有す る電気二重層コンデンサーは, 従来のコンデンサーの主 たる用途であった電源平滑化，ノイズ吸収用などの用途 以外にバックアップ電源, 二次電池の補助, 代替などの 用途に用いられるようになってきた。従来の二次電池は 高容量を有するが, 比較的寿命が短く, 急速な充放電が 困難であったことに対して，電気二重層コンデンサーは 比較的大きな容量を持ちながら, コンデンサーの本来の 長所である長寿命, 急速充放電が可能という好特性を併 せ持つため, 前述した用途に適用可能となった。すなわ ち, 電気二重層コンデンサーは, 従来の二次電池とコン デンサーの両者の長所が要求される用途分野に適合した デバイスであると言えよう。ここではこの電気二重層コ ンデンサーの動作原理と特徴などについてまず述べ, 次 いで我々が検討を進めている電気二重層コンデンサーの 高性能化を目指した最近の研究について紹介する。

\section{2. 電気二重層コンデンサーとは}

電気二重層コンデンサーの原理を図 1 に示す。通常の コンデンサーは対向させた二枚の電極の間に誘電体を挟 んだ構造をとっており, それぞれの電極に反対符号の電 荷が蓄積される。それに対し, 電気二重層コンデンサー では分極性電極表面に電解液中のイオンが吸着され，そ れによって生ずる電極と電解液界面の電気二重層に電荷 を蓄積する。この原理に基づけば, 通常のコンデンサー

*山口大学 工学部（干755 山口県宇部市常盤台 2557）

Fac. of Eng., Yamaguchi Univ. (2557 Tokiwadai, Ubeshi, Yamaguchi 755)

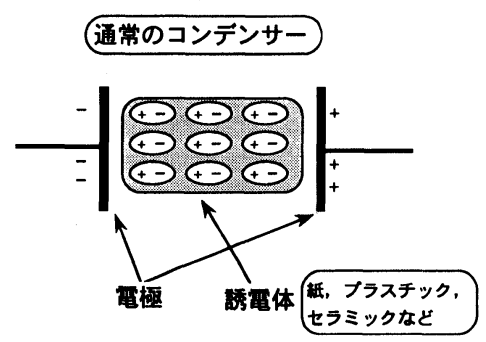

電気二重庿コンデンサー

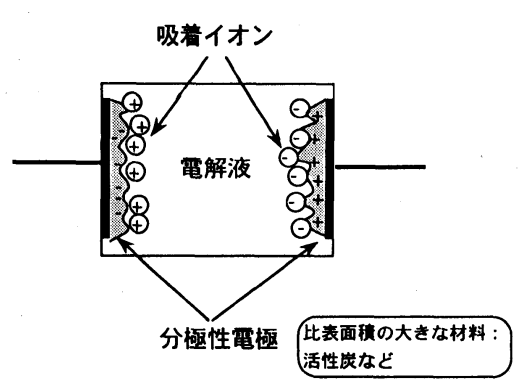

図 1 通常のコンデンサーと電気二重層コンデンサーの構成比較

に比べ遥かに多くの電気量を蓄積することができる。こ の電気二重層に効率よく多くの電荷を蓄積することが高 性能化のポイントとなる。電気二重層を高容量化するに は, 電極表面そのあのの改質とともに電極表面に接する 電解質の改良という, 二つのアプローチが重要であると 我々は認識している。以下ではこの両者の観点から試み た高性能化について述べる。 


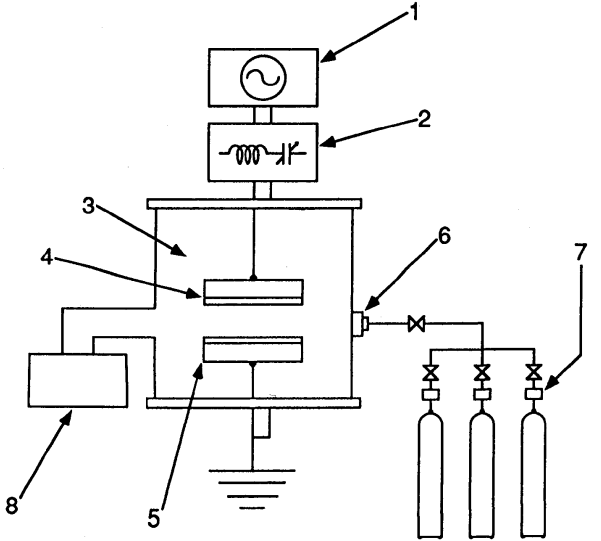

図 2 低温プラズマ処理に利用したプラズマCVD装置の概要

$1:$ 高周波電源 2 : マッチングボックス

3 : 放電チャンバー 4 : 連続電源用電極

5 : パルス電源用電極 6 : ガス導入口

$7:$ 流量コントローラ 8 : 真空ポンプ

\section{3. 高性能化の検討}

\section{1 炭素電極材料の表面物性の改善}

3. 1.1 低温プラズマ法による表面処理

電気二重層コンデンサーのキャパシタンスを担う電極 としては電極自身が電気化学的に不活性であり, かつ比 表面積の大きな $\left(1000 \sim 2000 \mathrm{~m}^{2} \mathrm{~g}^{-1}\right)$ 活性炭材料が一 般的に用いられる。そしてこの電極は, 分解反応などの 副反応を起こすことなく，電解質イオンを可逆的にでき るだけ多く吸着できる能力を持つことが望まれる。した がって, 電極表面の比表面積, 細孔分布ならびに表面官 能基の種類や分布に着目することは意義深い。

これまで報告されている，電気二重層コンデンサー用 炭素電極材料の改善法は, 熱処理 ${ }^{12,2)}$, 電気化学的酸 化処理 ${ }^{3)}$, あるいは電気化学的酸化還元処理 ${ }^{4)}$ な゙゙があ る。これらいずれの処理においてす物性変化は，材料表 面においてだけではなく，材料バルクにおいてあ認めら れるようである。これらの処理法は，それぞれ優れた点 があり実用性あ充分であるが，材料バルクの性質は変化 させず表面物性のみを変化させる検討も，より優れた材 料探索のためには不可欠であると考えられる。我々はこ れらの電極物性を改善するために低温プラズマ処理を電 極材料に対して適用し，電極バルクの性質を変化させず, 表面物性のみの改善を試みた ${ }^{5)}$.6)。以下にその検討結 果を述べる。

低温プラズマ処理は，低圧のグロー放電により発生さ せたプラズマによる処理のことを意味し，織維 ${ }^{7)}$, 樹脂 などの高分子材料 ${ }^{8)}$ ， あるいは炭素材料 ${ }^{9) \sim 12)}$ の表面処 理に利用されている。材料加工の表面処理技術は一般に 電気化学的処理, 化学薬品処理などの湿式法と乾式法に
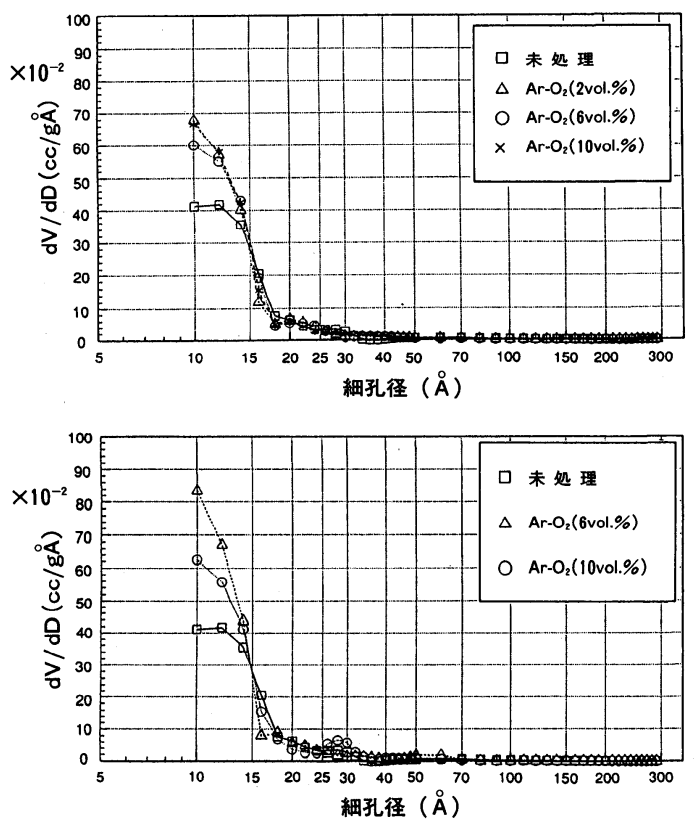

図 3 炭素電極上の細孔分布に対するプラズマ処理の効果 ${ }^{5)}$ （上）パルス電源使用,（下）連続電源使用

分類される。低温プラズマ処理はこのうち乾式法に当て はまり, 湿式法で避けれない水, 有機溶剂などの廃水処 理や，材料乾燥過程に必要なエネルギーを低温プラズマ 処理では回避することができる7”。加えて低温プラズマ 処理は処理条件をコントロールすることにより, 前述の ように材料ごく表面のみを改質可能なことが大きな特徴 である。我々は図 2 に示すようなプラズマ CVD装置を 利用し，処理を行った。すなわち，活性炭纎維布をプラ ズマチャンバーに設置した後 1 トール以下にチャンバー を脱気し，アルゴンと酸素の混合ガス $\left(\mathrm{Ar}-\mathrm{O}_{2}\right)$ を導入 してプラズマを発生させた。この際, プラズマ発生のた めの高周波電源 $(10 \mathrm{MHz}$ 程度) として, 連続的に作動 する連続電源，または間欠的に作動するパルス電源を選 択して使用できる。連続電源を使用する際には $100 \mathrm{~W}$ 程 度の出力を加えて処理を行い，一方パルス電源を用いる 際にはそれより大きな $10 \mathrm{~kW}$ 程度の出力を間欠的に加え ることができる。また，混合ガスの混合比や供給流速は 自由に設定できる。

電気二重層コンデンサー用活性炭繊維布にプラズマ処 理を 30 分行った際の，綫維表面の細孔分布を図 3 に示 す5)。図 3 中の vol. \%はチャンバーに導入したアルゴ ン，酸素混合ガス中の酸素ガスの体積百分率を表わして いる。パルス電源使用ならびに連続電源使用いずれにお

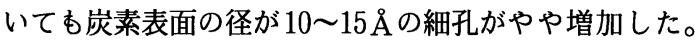
また，この材料の比表面積をガス吸着法により測定した ところ，プラズマ処理の有無によらず約 $13 \times 10^{2} \mathrm{~m}^{2} \mathrm{~g}^{-1}$ 


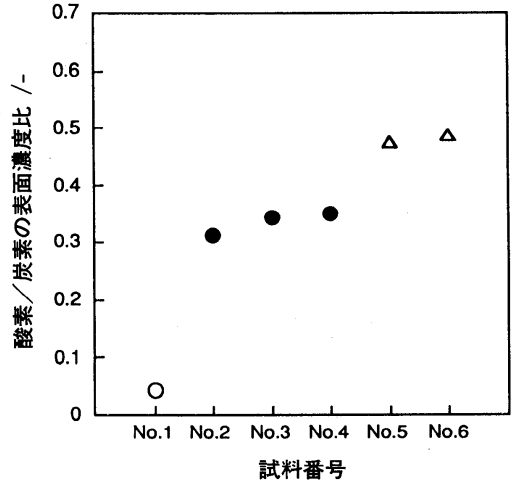

図 4 炭素電極上における酸素 $/$ 炭素濃度比 ${ }^{5)}$ №. 1 : 未処理

№. 2 : $\mathrm{Ar}_{-} \mathrm{O}_{2}$ ( 2 vol.\%) パルス №. 3 : $\mathrm{Ar}-\mathrm{O}_{2}(6$ vol.\%) パルス №. 4 : $\mathrm{Ar}_{-} \mathrm{O}_{2}(10 \mathrm{vol} . \%)$ パルス No. $5: \mathrm{Ar}-\mathrm{O}_{2}$ ( 6 vol.\%) 連続 No. 6 : $\mathrm{Ar}-\mathrm{O}_{2}(10 \mathrm{vol} . \%)$ 連続

であり，処理によって殆ど変化しない ${ }^{5)}$ 。一方，材料表 面上に存在可能性のある元素種の分布について, エック 又線光電子分光法 (XPS) によって水素以外の元素に つき解析したところ，ほぼ炭素と酸素のみが分布してい ることが分かった。未処理材料では酸素の量は僅かであ るが，プラズマ処理を行えば表面酸素の量が大幅に増加 した (図 4) $)^{5}$ 。このように比表面積, 細孔分布などの 表面物性は低温プラズマ処理によってあまり変化しない あのの, 表面の化学組成はかなり変化することが判明し た。

さらに走查型電子顕微鏡（SEM）により低温プラズ マ処理前後の炭素繊維の形態を調べたところ, 上述の表 面物性測定では得られなかった，プラズマ発生のための 電源の違いによる特徴が観察された。すなわち連続電源 を用いた処理では未処理材料表面では見られなかった比 較的大きな ( $1 \mu \mathrm{m}$ 程度) 多数の凹部が認められた。これ に対し，パルス電源を用いた処理では微細な凹部 $(0.1$ $\mu \mathrm{m}$ 以下) のみ認められた。さらに処理前後の材料の重 量測定を行ったところ，連続電源処理では炭素繊維の一 部燃焼によるものと考えられる10\%程度の重量減少が 認められた。これらの検討より，アルゴンと酸素混合ガ スによるプラズマでは，連続電源による処理を行うと低 出力の低温プラズマといえどあ材料バルクまで処理の影 響が及んでおり形態変化や重量減少が起こるが，パルス 電源による処理では効果はほぼ表面のみに限定されるこ とが明らかになった。

3. 1. 2 処理電極を用いたコンデンサー特性

実際に，これらプラズマ処理を施した炭素材料を電気 二重層コンデンサーの電極に適用し，充放電サイクル特
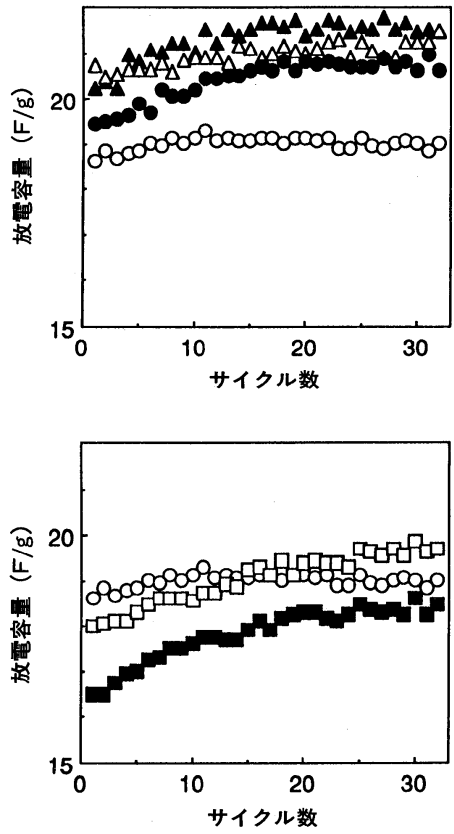

図 5

コンデンサーの放電容量のサイクル依存性に対するプラ ズマ好理の効果 ${ }^{5)}$

電解液 : $\mathrm{PC} / \mathrm{TEABF}_{4}(0.8 \mathrm{M})$, 充放電電流 : $1.0 \mathrm{~mA}$, 動作電圧 : $1-2 \mathrm{~V}$

$\mathrm{O}$ : 未処理, $: \mathrm{Ar}^{-\mathrm{O}_{2}}(2 \mathrm{vol} \%$ ) パルス, $\triangle: \mathrm{Ar}$ $\mathrm{O}_{2}(6 \mathrm{vol} . \%)$ パルス, $\boldsymbol{\Delta}: \mathrm{Ar}_{-} \mathrm{O}_{2}(10 \mathrm{vol} . \%)$ パルス, $\square: \mathrm{Ar}-\mathrm{O}_{2}(6 \mathrm{vol} . \%)$ 連続， $\square$ : $\mathrm{Ar}-\mathrm{O}_{2}$ (10vol.\%) 連続

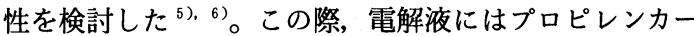
ボネート ( $\mathrm{PC})$, 電解質塩にはテエトラエチルアンモニ ウム四フッ化ホウ酸塩 $\left(\mathrm{TEABF}_{4}\right)$ を $0.8 \mathrm{~mol} \mathrm{dm}^{-3}(\mathrm{M})$ 濃度で用いた。連続電源を用いたプラズマ処理電極では 未処理電極に比べ，放電容量の増加は認められなかった （図 5 ）。一方，パルス電源によるプラズマ処理電極を用 いた場合，未処理電極に比べ明らかに放電容量の増加が 認められた（図 5 ）。連続電源を用いた処理では電極を 構成している炭素瀻維が前述のように形態変化や重量減 少を伴うので, 縅維間の接触抵抗の増加や電極の単位重 量あたりの充放電電流の增加によるキャパシタンス（放 電容量）減少の可能性が考えられる ${ }^{13)}$ 。いずれにしてあ これらの要因はコンデンサー用電極にとって好ましくな い材料バルクの変化である。それに対して材料バルクの 変化の少ないパルス発生による低温プラズマ処理では, 表面の改質が容量増加をあたらしたと考えられる。この 改善効果については前述の材料表面における細孔分布の 変化ならびに表面酸素官能基の増加がともに寄与してい るものと考えられる。電気二重層コンデンサーにおいて は充電時には電解質塩のカチオン（テトラエチルアンモ ニウムイオン）とアニオン（四フッ化ホウ酸イオン）が 


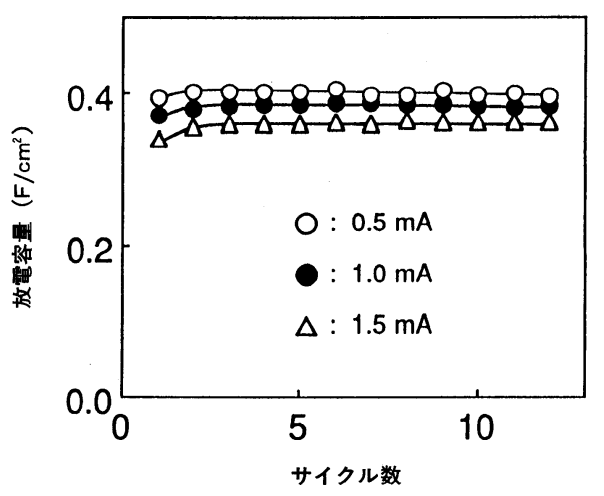

図 6 コンデンサーの放電容量のサイクル依存性に対する充放 電電流の影響 ${ }^{16)}$

$\mathrm{PAN}(68 \mathrm{mg}) / \mathrm{TEABF}_{4}(52 \mathrm{mg}) / \mathrm{PC}\left(6.5 \times 10^{2} \mathrm{mg}\right)$, 動作電圧 : $1-2 \mathrm{~V}$

反対方向に泳動し，それぞれ対向する電極に吸着する。 最近の筆者らの検討によれば ${ }^{6)}$, パルス低温プラズマの 容量増加効果はアニオン吸着極とカチオン吸着極の両極 に対して現れるが，特にカチオン吸着極に対して効果が 顕著であることが分かった。従って処理による酸素官能 基増加が吸着するカチオンとの静電的相互作用を安定化 させている可能性屯考えられる。

以上の結果から，パルス的に発生させた低温プラズマ を用いることにより，炭素電極材料のバルクの性質を殆 ど変化させることなく表面物性のみを好適に改善できる ことが見出された。

\section{2 ゲル型高分子固体電解質の適用}

この節では前節で紹介したような電極側からの界面特 性の改善に対して, 電解質の改良による界面特性の向上 について紹介する。電気二重層コンデンサーは電解液の 種類で分類すると, 水溶液型と有機電解液型とに分けら れる。水溶液型は耐電圧が原理的に低いのが欠点 $(1.3 \mathrm{~V}$ 以下）であるため，前節で報告したように耐電圧が高い PCを溶媒とした有機電解液型を我々は検討してきた。 この有機電解液系を固体化した有機固体電解質を適用す ることにより, 充電時に電極界面に吸着したイオン種の 泳動による拡散を防ぎ，漏れ電流の低減，自己放電の抑 制を実現できる可能性がある。このほかにも重要な利点 として, 電解液の漏液の回避, 高温における特性の改善, 薄膜化，小型化が可能になると見込まれている。しかし ながら一般的に固体化すると内部抵抗が高くなり，従っ て急速充放電には不利になる。我々はこれを克服するた めにゲル型高分子固体電解質を電気二重層コンデンサー に適用することを試みた ${ }^{13) \sim 16) 。 ~}$

固体電解質のマトリックスとしてポリエーテルを側鎖 に持つポリエチレンオキシドグラフトポリメチルメタク リレート(PEO-PMMA)を光重合により合成した。こ
れに電解質塩として前述の $\mathrm{TEABF}_{4}$ に代表される四級 アンモニウム塩, ゲル化させるための可塑倣として PC を含むゲル型高分子膜は室温において有機電解液より一 桁ほど低い伝導度を示した $\left(3 \times 10^{-4} \mathrm{~S} \mathrm{~cm}^{-1}\right)^{13), 14)}$ 。一 方，マトリックスとしてポリアクリロニトリル（PAN） を適用し，四級アンモニウム塩（TEABF 4 など）およ び PCを含むゲル型電解質は, PEO-PMMA系よりも 機械的強度の高いゲル膜として得られた ${ }^{15), ~}{ }^{16)}$ 。加え てこの膜の伝導度は極めて良好であり, 室温において $10^{-3} \mathrm{~S} \mathrm{~cm}^{-1}$ オーダーであり通常の液体有機電解液系と ほぼ同等であることが分かった。

これら 2 種のゲル型固体電解質 (PEO-PMMA系お よび PAN系）をそれぞれコンデンサーの電解質に適用 し, 充放電サイクル特性を検討した。PAN系コンデン サーの放電容量（図 6 : 電極面積は $2.3 \mathrm{~cm}^{2}$ ） は PEOPMMA系ととあに好特性であった。また, 充放電の電 流を変化させた場合, 例えば電流を $0.5 \mathrm{~mA} ら ~ 1.5 \mathrm{~mA}$ 之増加させた時, PEO-PMMA系では容量が $35 \%$ あ減 少したのに対し,PAN系では図6のように15\%ほどの 減少にとどまり, PAN系の方が急速充放電により適す ることが分かった。

電極の表面には大小さまざまな細孔が存在し，これら が充電時のイオン吸着のサイトになると考えられている。 しかしながら，これらのサイトはすべて同じ効率でイオ ンが吸着するのではなく, 物理的ならびに電気的な抵抗 が少ないサイトほど有効に吸着が起こると考えられる。 いいかえれば大電流で充電を行うほど，抵抗の大きなサ イトはIRドロップにより充電がされにくい(イオン 吸着が起こりにくい)ことになる。本研究では $\mathrm{PEO}$ PMMAを電解質に用いた場合よりも，イオン伝導度が より優れた PANを用いたほうが電流の大小による容量 の変化が少なかった。このことは電極表面に接する電解 質の伝導度が電極表面のイオン吸着サイトの抵抗を大き く支配しているためと考えられる。さらに，自己放電特 性（コンデンサーを開回路にした時にどれだけ長い時間 所定の電圧を維持できるかという特性）は本研究におけ るゲル型固体電解質 (PEO-PMMA系ならびに PAN 系）を使用したコンデンサーの方が, 通常の溶液型コン デンサーより優れていた。これは電極表面の吸着イオン の拡散が溶液系のコンデンサーに比べ，抑制されたため と考えられる。

\section{4. おわりに}

材料バルク本来の性質を維持させたままで, 表面物性 をデリヶートに変化させることが可能な低温プラズマ処 理法は, 表面物性の改善で材料の付加価值を高めるこ之 が可能な優れた，かつ環境に対してクリーンなプロセス の一つであると言える。本解説で取り上げた電気二重首 
コンデンサーは，電極界面の特性がコンデンサー全体の 性能を大きく支配するデバイスである。従ってこのよう なプラズマ処理による電極側からの改善ととあに, 電極 界面特性を支配する電解質側からの改善も忘れてはなら ない。

最後に，本解説中で紹介した我々の研究を共同で遂行 した山口大工学部の森田昌行助教授, 山口県工業技術セ ンターの石田浩一氏に感謝する。また松下電子部品(侏), 山口松下電器(㑣), 東洋紡績(侏), (㑣)トクヤマに材料提供な らびに有益な情報を頂いた。記して謝意を表する。

(1996-2-21 受理)

\section{文献}

1) M. Ishikawa, M. Morita, S. Yamashita, Y. Matsuda ; Prog. Batteries Battery Mater., 13, 404 (1994)

2 ) I. Tanahashi, A. Yoshida, A. Nishino ; J. Electrochem. Soc., 137, 3052 (1990)

3 ) T. Momma, X. Liu, T. Osaka, Y. Ushio, Y. Sawada ; J. Power Sources, in press
4 ) 劉 興江, 門間聴之, 逢坂哲㣂; 電気化学, 64, 143 (1996)

5 ) M. Ishikawa, A. Sakamoto, M. Morita, Y. Matsuda, K. Ishida ; J. Power Sources, in press

6) 坂本 敦, 石川正司, 森田昌行, 松田好晴, 石田浩一 ; 1995 年電気化学秋季大会講演要旨集, p. 28 (1995)

7）脇田登美司, 解野誠司 ; 表面技術, 46, 1003 (1995)

8 ) T. Wakida, H. Kawamura, J. Song, T. Goto, T.

Takagishi ; Sen'i Gakkaishi, 43, 384 (1987)

9 ) C. Jones, E. Sammann ; Carbon, 28, 509 (1990)

10) C. Jones, E. Sammann ; Carbon, 28, 515 (1990)

11) I. H. Loh, R. E. Cohen, R. F. Baddour ; J. Mater. Sci., 22, 2937 (1987)

12) S. Mujin, H. Baorong, W. Yisheng, T. Ying, $H$. Weiqin, D. Youxian ; Compos. Sci. Tech., 34, 353 (1989)

13) M. Ishikawa, M. Morita, M. Ihara, Y. Matsuda ; J. Electrochem. Soc., 141, 1730 (1994)

14) Y. Matsuda, M. Morita, M. Ishikawa, M. Ihara ; $J$. Electrochem. Soc., 140, L109 (1993)

15) M. Ishikawa, M. Ihara, M. Morita, Y. Matsuda ; Denki Kagaku, 62, 722 (1994)

16) M. Ishikawa, M. Ihara, M. Morita, Y. Matsuda ; Electrochim. Acta, 40, 2217 (1995)

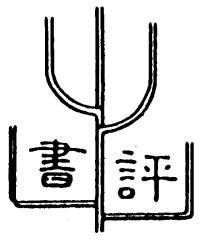

\section{電気めっきガイド'95版}

\section{全国鍍金工業組合連合会 編}

\section{$¥ 4,000$-（消費税込）}

全国鍍金工業組合連合会より，電気めっき技術レベル の解説を中心とした「電気めっきガイド'95版」が発刊 されました。電気めっきは素材あるいは製品に多用な特 性を付与するだけでなく，省資源，省エネルギーならび に無公害などの自然環境にやさしい技術を有しています。 将来の表面処理技術を展望したとき，これらの特徴を表 面処理分野の方々に正しく理解していただけるよう構成 されています。

本書の内容は，1）表面処理の種類，2）要求特性と めっき（装飾，防錆, 工業用, 各種機能めっき), 3 ) 素材之電気めっき（各種金属, 非金属系)，4）設計上 の留意点，5）電気めっきの応用例（エレクトロニクス, 精密部品)，6）電気めっきの複合技術（高度化, 印刷, 着色, 塗装, クロメート処理など)， 7 ）電気めっきと
JIS，からなっており，さらに目的とする皮膜特性とめっ きの種類，皮膜特性の概要と用途例の関係が，付表によっ て整理されています。

本書はカラー化されているので技術の現状や製品の特 徵などが極めて理解しやすく，またレイアウトにす工夫 がなされて分かりやすい。現状の技術レベルからハイテ ク分野に至る最新技術まで網羅されているので，電気めっ き関係企業の開発，技術，設計担当者はもとより，この 分野の研究者にとってあ良き解説書となりましょう。

(関東学院大学 山下 嗣人)

\footnotetext{
* 全国鍍金工業組合連合会（テ105 東京都港区芝公園 3-5-8 機
} 械振興会館 303-2，803-3433-3855） 